DARK MATTERS 



\title{
Dark Matters
}

\author{
PESSIMISM AND THE \\ PROBLEM OF SUFFERING
}

RNM

Mara van der Lugt 
Copyright (C) 2021 by Princeton University Press

Requests for permission to reproduce material from this work should be sent to permissions@press.princeton.edu

Published by Princeton University Press

41 William Street, Princeton, New Jersey 08540

6 Oxford Street, Woodstock, Oxfordshire OX20 1TR

press.princeton.edu

All Rights Reserved

ISBN 9780691206622

ISBN (e-book) 9780691226156

British Library Cataloging-in-Publication Data is available

Editorial: Ben Tate and Josh Drake

Production Editorial: Debbie Tegarden and Natalie Baan

Jacket Design: Karl Spurzem

Production: Danielle Amitucci

Publicity: Alyssa Sanford and Amy Stewart

Copyeditor: Geoffrey D. Palmer

Page vii: Quote from Paul Kingsnorth, The Wake (London: Unbound, 2015).

(C) Paul Kingsnorth 2014; first published in the UK by Unbound.

Page 28: Quote from Muriel Spark, The Only Problem (Edinburgh: Polygon, 2017).

Page 395: Quote from 'Anthem.' Words and Music by Leonard Cohen (C) 1992.

Reproduced by permission of Sony/ATV Songs LLC, London W1T ${ }_{3} L P$.

This book has been composed in Miller

Printed on acid-free paper. $\infty$

Printed in the United States of America

1098776554321 
In memory of my father

Bart van der Lugt

(1942-2006) 

who will hiere the gleoman when the tales he tells is blaec who locs at the heofon if it brings him regn

who locs in the mere when there seems no end to its deopness

PAUL KINGSNORTH, THE WAKE

Éléments, animaux, humains, tout est en guerre.

Il le faut avouer, le mal est sur la terre...

\section{VOLTAIRE}

.. die Philosophie hebt, wie die Ouvertüre zum Don Juan, mit einem Mollakkord an.

ARTHUR SCHOPENHAUER

Je vois le mal sur la terre.

JEAN-JACQUES ROUSSEAU 
